\title{
Heterogeneity among smokers and non-smokers in attitudes and behaviour regarding smoking and smoking restrictions
}

Department of Public Health Sciences, University of Toronto, and Ontario Tobacco Research Unit, Centre for Health Promotion, University of Toronto, Toronto, Ontario,

Canada

B D Poland

J E Cohen

M J Ashley

Centre for Addiction and Mental Health,

Toronto

E Adlaf

Ontario Tobacco

Research Unit, Centre for Health Promotion, University of Toronto, and Centre for

Addiction and Mental

Health, Toronto

R Ferrence

Department of Community Health and Preventive

Medicine, Moorehouse

School of Medicine,

Atlanta, Georgia, USA

L L Pederson

Ontario Tobacco

Research Unit, Centre for Health Promotion, University of Toronto, and Samuel Lunenfeld Research Institute, Mount Sinai Hospital, Toronto

S B Bull

Department of Public Health Sciences, University of Toronto D Raphael

Correspondence to: Professor Blake Poland, Department of Public Health Sciences, Faculty of Medicine, University of Toronto, McMurrich Building, 12 Queen's Park Crescent West, Toronto, Ontario M5S 1A8, Canada; blake.poland@utoronto.ca

Received 8 October 1999 and in revised form

19 May 2000.

Accepted 1 June 2000

Blake D Poland, Joanna E Cohen, Mary J Ashley, Ed Adlaf, Roberta Ferrence, Linda L Pederson, Shelley B Bull, Dennis Raphael

Abstract

Objective-To determine if smokers and non-smokers cluster into meaningful, discrete subgroups with distinguishable attitudes and behaviours regarding smoking and smoking restrictions.

Design-Qualitative research with 45 smokers guided development of questionnaire items applied in a population based telephone survey of 432 current smokers and 1332 non-smokers in Ontario, Canada. Methods-Cluster analysis of questionnaire items used to categorise adult smokers and non-smokers; comparison of clusters on sociodemographic characteristics and composite knowledge and attitude scores.

Results-Smokers clustered in three groups. "Reluctant" smokers (16\%) show more concern about other people discovering that they smoke, but parallel "easygoing" smokers (42\%) in supporting restrictions on smoking and not smoking around others. "Adamant" smokers $(42 \%)$ feel restrictions have gone too far, and are less likely to accommodate non-smokers. Significant gradients across categories in the expected direction were observed with respect to smoking status, stage of change, knowledge, and attitude scores, and predicted compliance with restrictions, validating the proposed typology. Non-smokers also clustered into three groups, of which the "adamant" non-smokers (45\%) are the least favourably disposed to smoking. "Unempowered" non-smokers (34\%) also oppose smoking, but tend not to act on it. "Laissez-faire" non-smokers (21\%) are less opposed to smoking in both attitude and behaviour. A significant gradient across categories in the expected direction was observed with respect to composite scores regarding knowledge of the health effects of active and passive smoking and a composite score on support for restrictions on smoking in public places.

Conclusion-Recognition and consideration of the types of smokers and non-smokers in the population and their distinguishing characteristics could inform the development of tobacco control policies and programmes and suggest strategies to assist implementation.

(Tobacco Control 2000;9:364-371)

Keywords: smokers; non-smokers; attitudes; smoking restrictions; typology; cluster

The heterogeneity of smokers and nonsmokers on a number of dimensions has been previously documented. Smokers have been categorised according to their level of nicotine dependence, ${ }^{1-3}$ their progression towards abstinence, ${ }^{4-6}$ and their pattern and frequency of cigarette consumption. ${ }^{78}$ We have found that smoking related characteristics, and knowledge and attitudes about tobacco, vary according to these classifications..$^{9-11}$ Likewise, non-smokers and smokers differ in terms of attitudes towards smoking and restrictions on smoking in public places. ${ }^{12-17}$ However, little is known about the extent to which smokers and non-smokers might be classified on the basis of their attitudes and behaviours regarding smoking and smoking restrictions.

Earlier qualitative research conducted in 1993 with 45 smokers in Brantford Ontario, as part of the evaluation of the US National Cancer Institute's Community Intervention Trial for Smoking Cessation (COMMIT) smoking cessation intervention trial, ${ }^{18}{ }^{19}$ suggested that a typology of smokers might exist with respect to attitudes and behaviours related to environmental tobacco smoke. The testimony provided by respondents suggested the existence of distinct groups of smokers with regard to their reactions to restrictions on smoking in public places and growing social pressure to quit. $^{20}$

The "reluctant" smokers seemed to feel considerable social pressure to quit, frequently expressed feelings of guilt about smoking, and often hid the fact that they smoked from others. In many cases, they participated in social networks at work or in their private lives in which non-smoking had become the norm. In this context, frequent verbal and non-verbal cues served as potent reminders of the declining social acceptability of smoking. To a greater 
extent than "easygoing" smokers or "adamant" smokers, they seemed to have internalised this stigma as guilt and self-blame, seeing smoking as a personal blemish and a source of "dis-ease", as exemplified in the following quotes.

"I try not to smoke as much any more when I am in other company because it is so unacceptable these days, and they want to make you feel so shitty, so when I am out in a social situation I don't smoke nearly as much as I used to, especially at parties and people's homes or meetings."

"It's weird . . .if I'm sitting at a bench or something like that, I won't have one . . .because it's too open .... I get to the point where I'm too embarrassed to have a smoke . . .because I just don't think it looks good."

Most "easygoing" smokers considered it self evident that non-smokers should not have to breathe their smoke. These smokers expressed interest in quitting some day, and appeared willing to compromise in order to accommodate others. Deciding whether or not to smoke in particular settings was a function of how well they thought it would be received by those around them, and this was generally not viewed as a problem. In the words of one "easygoing" smoker:

Table 1 Items used in the cluster analysis (smokers)

\begin{tabular}{|c|c|c|}
\hline Short name & Question wording & Response categories \\
\hline CareKnow & $\begin{array}{l}\text { Do you care if most people know you } \\
\text { smoke? }\end{array}$ & $\begin{array}{l}\text { yes; } \\
\text { no }\end{array}$ \\
\hline Enjoy & $\begin{array}{l}\text { You enjoy smoking. Is this a reason } \\
\text { why you smoke? }\end{array}$ & $\begin{array}{l}\text { yes; } \\
\text { no }\end{array}$ \\
\hline ReduceSm & $\begin{array}{l}\text { Everything possible should be done } \\
\text { to reduce smoking. Do you ... }\end{array}$ & $\begin{array}{l}\text { strongly agree; } \\
\text { somewhat agree; } \\
\text { somewhat disagree; } \\
\text { strongly disagree }\end{array}$ \\
\hline Enough & $\begin{array}{l}\text { There are enough controls on } \\
\text { smoking and we should leave } \\
\text { smokers alone. Do you ... }\end{array}$ & $\begin{array}{l}\text { strongly agree; } \\
\text { somewhat agree; } \\
\text { somewhat disagree; } \\
\text { strongly disagree }\end{array}$ \\
\hline UpRestr & $\begin{array}{l}\text { Restrictions should be increased to } \\
\text { help smokers quit. Do you ... }\end{array}$ & $\begin{array}{l}\text { strongly agree; } \\
\text { somewhat agree; } \\
\text { somewhat disagree; } \\
\text { strongly disagree }\end{array}$ \\
\hline SmRights & $\begin{array}{l}\text { Restrictions have gone too far and } \\
\text { smokers need to start standing up for } \\
\text { their rights. Do you... }\end{array}$ & $\begin{array}{l}\text { strongly agree; } \\
\text { somewhat agree; } \\
\text { somewhat disagree; } \\
\text { strongly disagree }\end{array}$ \\
\hline Rules & $\begin{array}{l}\text { Which of the following best describes } \\
\text { the rules about smoking in your } \\
\text { home for people who live there? }\end{array}$ & $\begin{array}{l}\text { smoking is not allowed; } \\
\text { some rules; } \\
\text { no rules }\end{array}$ \\
\hline VisitH & $\begin{array}{l}\text { When non-smokers visit you in your } \\
\text { own home, do you ... }\end{array}$ & $\begin{array}{l}\text { not smoke at all; } \\
\text { ask if they mind if you smoke; } \\
\text { or just go ahead and smoke }\end{array}$ \\
\hline SitNsm & $\begin{array}{l}\text { In the past year, have you sat in a } \\
\text { non-smoking area of a restaurant } \\
\text { because you were with a } \\
\text { non-smoker? }\end{array}$ & $\begin{array}{l}\text { yes; } \\
\text { no }\end{array}$ \\
\hline SmAround & $\begin{array}{l}\text { Which of the following statements } \\
\text { best describes how you feel about } \\
\text { smoking around non-smokers }\end{array}$ & $\begin{array}{l}\text { you tend to avoid smoking; } \\
\text { you ask if it's OK to smoke; } \\
\text { you feel that if non-smokers do not } \\
\text { like your smoke they can go } \\
\text { somewhere else }\end{array}$ \\
\hline
\end{tabular}

Questions were not asked in this order, and were not always contiguous within the larger survey questionnaire.
“ . . . if they say 'Don't smoke here' fine, I won't. I don't feel that's pressure on me as a smoker. (If) you don't want me to smoke, fine, I won't smoke. It's not a big deal."

"Adamant" smokers were most apt to express resentment about government regulations being "rammed down our throats". Although few respondents identified themselves as "adamant" smokers, their existence as an growing force "to be reckoned with" was widely asserted by many interviewees in the Brantford study. Respondents characterised the "adamant" smoker as being indignant and sometimes defiant.

"I remember before I quit smoking . . .how angry I was at the government for all this media and all this put down of people that smoked .... I thought that we were people too, even if we had a habit, we were still people, you know."

The findings from this qualitative study led to the current attempt to replicate and validate this typology in a larger population based sample of smokers, and to assess the proportions of the smoking public in each group. We also postulated that just as smokers could be classified as "reluctant", "easygoing" or "adamant", based on their basic stance toward smoking and smoking restrictions, non-smokers could also be grouped on corresponding dimensions. Therefore, we sought to determine whether smokers and non-smokers could be classified, what the nature of such a typology would be, and what relative proportions of the smoking and non-smoking adult public could be assigned to each group.

\section{Methods}

Based on the qualitative research summarised above, ${ }^{18} 19 \quad 10$ questionnaire items were developed (table 1) to differentiate current smokers according to: (a) whether they cared if others knew they smoked (item 1); (b) how they felt about their own smoking (item 2); (c) attitudes towards smoking restrictions (items 3-6); and (d) their own behaviours regarding smoking around others in private and public spaces (items 7-10). (Responses were coded and standardised to produce variables with a mean of 0 and a standard deviation of 1. Copies of the interview schedule are available on request.) These items were selected because they most closely reflected the distinctions among categories identified in the qualitative research. In particular, the extent to which some smokers seemed concerned about whether others knew that they smoked (item 1) and the extent to which they enjoyed smoking (item 2) seemed to be the strongest factors differentiating "reluctant" smokers from other smokers. Framing restrictions as measures that help smokers quit (item 5) elicited different responses than when the issue was framed in terms of smokers' rights and restrictions having "gone too far" (item 6) or doing everything possible to reduce smoking (item 3) versus their being "enough controls" and needing to "leave smokers alone" (item 4). Thus, variations in wording in items 3-6 reflect discernable differences in stance which we 
Table 2 Items used in the cluster analysis (non-smokers)

\begin{tabular}{|c|c|c|}
\hline Short name & Question wording & Response categories \\
\hline ReduceSm & $\begin{array}{l}\text { Everything possible should be done to } \\
\text { reduce smoking. Do you ... }\end{array}$ & $\begin{array}{l}\text { strongly agree; } \\
\text { somewhat agree; } \\
\text { somewhat disagree; } \\
\text { strongly disagree }\end{array}$ \\
\hline Enough & $\begin{array}{l}\text { There are enough controls on smoking } \\
\text { and we should leave smokers alone. } \\
\text { Do you ... }\end{array}$ & $\begin{array}{l}\text { strongly agree; } \\
\text { somewhat agree; } \\
\text { somewhat disagree; } \\
\text { strongly disagree }\end{array}$ \\
\hline UpRestr & $\begin{array}{l}\text { Restrictions should be increased to } \\
\text { help smokers quit. Do you ... }\end{array}$ & $\begin{array}{l}\text { strongly agree; } \\
\text { somewhat agree; } \\
\text { somewhat disagree; } \\
\text { strongly disagree }\end{array}$ \\
\hline SmRights & $\begin{array}{l}\text { Restrictions have gone too far and } \\
\text { smokers need to start standing up for } \\
\text { their rights. Do you ... }\end{array}$ & $\begin{array}{l}\text { strongly agree; } \\
\text { somewhat agree; } \\
\text { somewhat disagree; } \\
\text { strongly disagree }\end{array}$ \\
\hline Mindhome & $\begin{array}{l}\text { How easy or difficult would it be for } \\
\text { you to ask someone not to smoke in } \\
\text { your home? }\end{array}$ & $\begin{array}{l}\text { very easy; } \\
\text { somewhat easy; } \\
\text { somewhat difficult; } \\
\text { very difficult; } \\
\text { don't mind if people smoke in home }\end{array}$ \\
\hline Rules & $\begin{array}{l}\text { Which of the following best describes } \\
\text { the rules about smoking in your home } \\
\text { for people who live there? }\end{array}$ & $\begin{array}{l}\text { smoking is not allowed; } \\
\text { some rules; } \\
\text { no rules }\end{array}$ \\
\hline AskNoSmk & $\begin{array}{l}\text { How easy or difficult would it be for } \\
\text { you to ask someone not to smoke in a } \\
\text { non-smoking area? }\end{array}$ & $\begin{array}{l}\text { very easy; } \\
\text { somewhat easy; } \\
\text { somewhat difficult; } \\
\text { very difficult; } \\
\text { wouldn't ask }\end{array}$ \\
\hline DoBother & $\begin{array}{l}\text { If someone was smoking in a } \\
\text { non-smoking area of a public place, } \\
\text { how likely are you to make a face, a } \\
\text { coughing noise, a loud comment, or } \\
\text { some other signal to get them to realise } \\
\text { that it is bothering you? }\end{array}$ & $\begin{array}{l}\text { very likely; } \\
\text { somewhat likely; } \\
\text { somewhat unlikely; } \\
\text { very unlikely; } \\
\text { not bothered by others' smoke }\end{array}$ \\
\hline Approach & $\begin{array}{l}\text { How likely are you to approach that } \\
\text { person and point out that they are in a } \\
\text { non-smoking area? }\end{array}$ & $\begin{array}{l}\text { very likely; } \\
\text { somewhat likely; } \\
\text { somewhat unlikely; } \\
\text { very unlikely }\end{array}$ \\
\hline SitSm & $\begin{array}{l}\text { In the past year, have you sat in a } \\
\text { smoking area of a restaurant because } \\
\text { you were with a smoker? }\end{array}$ & $\begin{array}{l}\text { yes; } \\
\text { no }\end{array}$ \\
\hline Restaur & $\begin{array}{l}\text { Suppose you arrive at a restaurant and } \\
\text { find that the only free tables are in the } \\
\text { smoking section. Do you think you } \\
\text { would... }\end{array}$ & $\begin{array}{l}\text { take a table in the smoking section } \\
\text { right away; } \\
\text { be willing to wait up to } 15 \text { minutes; } \\
\text { leave and go to another restaurant }\end{array}$ \\
\hline
\end{tabular}

Questions were not asked in this order, and were not always contiguous within the larger survey questionnaire.
Eleven questionnaire items were developed (table 2) to differentiate non-smokers according to their attitudes toward smoking restrictions (items 1-4), smoking in their home (items 5-6), likelihood of communicating displeasure with second hand smoke to smokers verbally or non-verbally (items 7-9), and willingness to sit in the smoking section of a restaurant if that was all that was available or to accommodate a smoker (items 10-11). Without the benefit of prior qualitative research (which had only been with smokers), the non-smoker items were developed to parallel closely those used to distinguish smokers (table 1), with the exception of items 7-9, which tap non-smokers' self-reported willingness to use non-verbal cues ${ }^{20}$ or directly approach smokers in public places.

In the spring of 1996, these questions were incorporated in a population based telephone survey in the province of Ontario, Canada, to assess smoking behaviours, knowledge of health effects of tobacco, attitudes toward tobacco, and support for tobacco control policy measures. ${ }^{20}{ }^{21}$ Respondents aged 18 years and older were selected using a two stage stratified sampling design. In the first stage, households were randomly selected using random digit dialling; the second stage involved the random selection of the respondent from adults in the household, based on most recent birthday. ${ }^{22}$ A total of 1764 computer assisted telephone interviews were completed, representing a response rate of $65 \%$ (calculated by dividing the number of completed interviews by the estimated number of eligible households). One quarter of respondents ( $n=432,24 \%$ ) currently smoked daily or less than daily. Non-smokers numbered 1332 ( $76 \%$ of the sample), 436 (33\%) of whom had formerly smoked.

A cluster analysis was undertaken using SPSS $^{23}$ to determine whether distinct groups of smokers and non-smokers existed in our representative sample. All variables were $z$ standardized, and each sample (smokers and non-smokers) was randomly divided in two- the "calibration" half and the "confirmation" half. Using the calibration half, a hierarchical cluster analysis (Ward's technique) was conducted to determine the best number of clusters. A K-means cluster analysis was then performed, based on cluster centres from the hierarchical analysis, to refine the solution further. This analysis was repeated using the confirmation sample. Two, three, and four cluster solutions were examined for both the calibration and the confirmation samples. The three cluster solution yielded the most comprehensible and parsimonious solution, with substantial agreement between subsamples (that is, similar distribution into the three clusters and similar profiles). Although ensuring that a specific clustering solution is the optimal or "correct" one can be quite difficult, two methods of evaluating clusters, (a) replication (on split halves of the sample), and (b) significance tests on "external" variables, ${ }^{24}$ were used. The findings from a three cluster solution performed on the recombined their predicted compliance with more restrictions on smoking. 


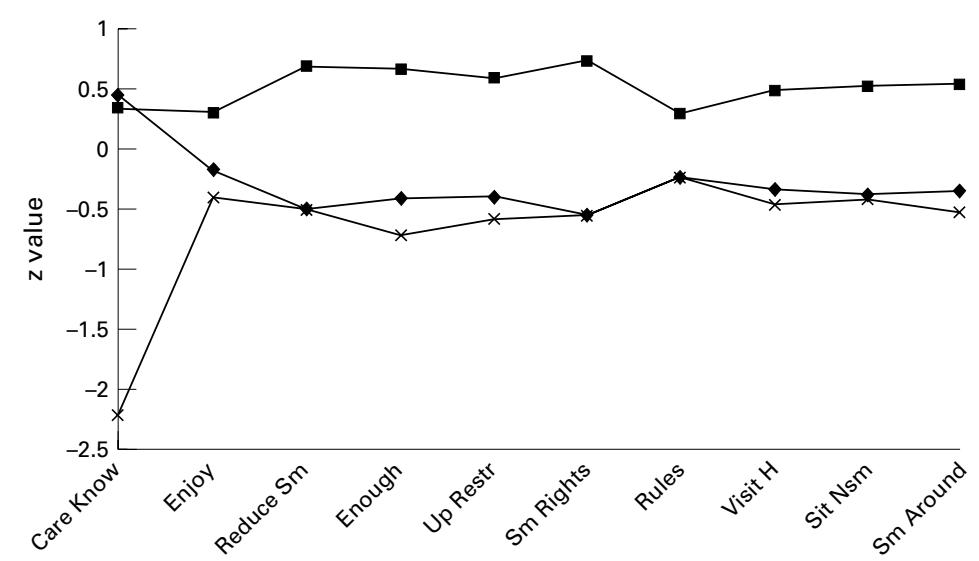

\begin{tabular}{ccc|}
\hline - Cluster 1 & $\diamond$ Cluster 2 & $\times$ Cluster 3 \\
\hline $\mathrm{n}=184$ & $\mathrm{n}=181$ & $\mathrm{n}=67$ \\
$42 \%$ & $42 \%$ & $16 \%$ \\
(Adamant) & (Easy going) & (Reluctant)
\end{tabular}

Figure 1 Profile of smokers.

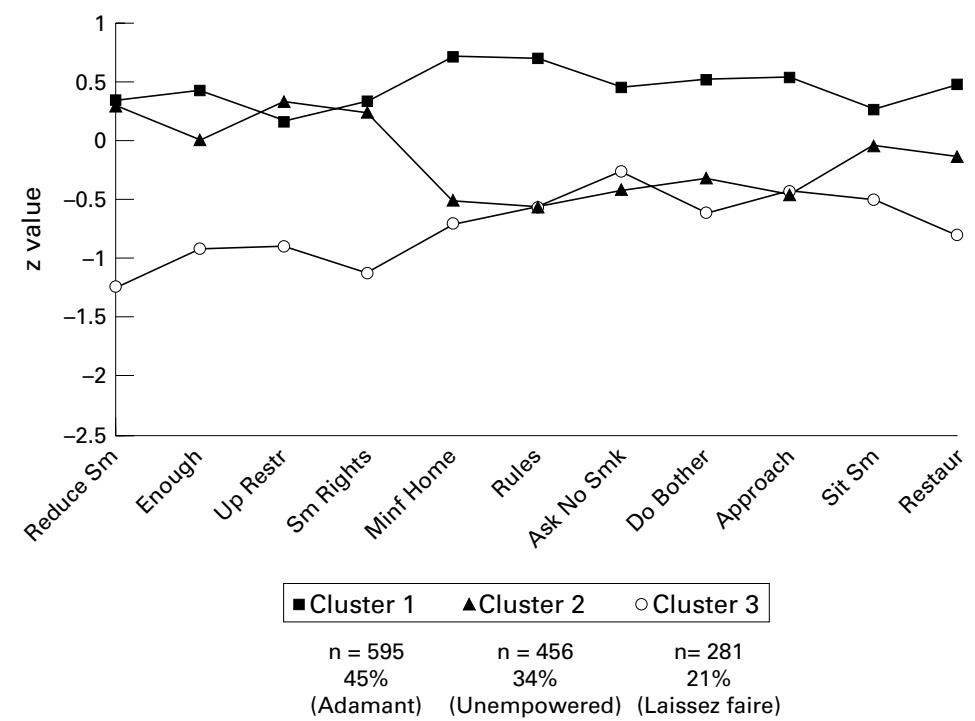

Figure 2 Profile of non-smokers.

samples, are reported here. (Results from the separate calibration and confirmation samples can be obtained from one of the authors (JC)).

Cluster centre means from the K-means cluster analysis were used to plot the profile of smokers and non-smokers. Cluster centres are the mean standardised ( $z$ value) scores on each variable, for each of the three clusters. The use of $z$ values allows the comparison of items that have varying numbers of response categories, as well as a visual representation of the proportions of each cluster agreeing or disagreeing with each of the items (see figs 1 and 2). Sociodemographic and smoking related characteristics were compared across clusters. External validity was examined by comparing responses to knowledge and policy attitude items across cluster groups. Design based tests of difference across clusters involved comparison of response proportions and response means. Summaries of knowledge regarding the health effects of both active and passive smoking, from 0 to 4, were obtained by summing correct answers to items asking about specific health effects of tobacco smoke. A summary measure of support for banning smoking in public places, ranging from 0 to 8 , was obtained by summing support for a ban in eight public places.

For the comparisons across clusters, observations were weighted, and adjustments were made for the complex survey design using Stata. ${ }^{25}$ Design based $\mathrm{F}$ tests were used to identify significant differences across the clusters.

\section{Results}

The three cluster solution for smokers produced the following distribution: $16 \%$ "reluctant" smokers, $42 \%$ "easygoing" smokers, and $42 \%$ "adamant" smokers. We retained the labels from the earlier qualitative study because they appeared to be descriptive of the characteristics of each group. We also found clearly discernable groups of non-smokers in terms of their stance toward smoking and smoking restrictions. The three cluster solution for non-smokers indicated that $43 \%$ could be classified as "adamant" non-smokers, 36\% could be classified as "unempowered" non-smokers, and $21 \%$ could be classified as "laissez-faire" non-smokers. The rationale for our selection of these labels is described below.

The $z$ values of the cluster centres for the 10-11 questionnaire items were plotted to permit a visual inspection of the cluster profile for smokers and non-smokers (figs 1 and 2, respectively). While "reluctant" and "easygoing" smokers were similar on most items, they differed greatly with respect to caring that other people knew that they smoked, with "reluctant" smokers being much more concerned. On the other hand, "adamant" smokers differed greatly from "reluctant" smokers on all items and from "easygoing" smokers on all but one item (caring if others know that they smoked). "Adamant" smokers were more likely to indicate that they enjoyed smoking (item 2), more likely to voice opinions that did not support further restrictions (items 3-6), less likely to have rules about smoking in their home (for self or others) (items 7-8), and less likely to defer to non-smokers (items 9-10). In short, the findings appear to confirm the existence of the three clusters found in the qualitative research.

Whereas "adamant" and "unempowered" non-smokers were similar in their less favourable attitudes toward smoking (items 1-4), they were notably different in their behaviours, with regard to both smoking in their homes (items 5-6) and in public places (items 7-9), and their unwillingness to compromise in "test" situations (items 10-11) (fig 2). The behaviour of the "adamant" non-smokers was consistent with their attitudes, whereas the "unempowered" nonsmokers failed to manifest their attitudes in their behaviour. "Laissez-faire" non-smokers were much more favourable to smoking than either "unempowered" or "adamant" nonsmokers, but they did not differ significantly from "unempowered" non-smokers in terms of their reported behaviour-specifically, in their 
Table 3 Sociodemographic and smoking related characteristics by cluster (smokers)

\begin{tabular}{|c|c|c|c|c|}
\hline \multirow[b]{2}{*}{ Characteristic } & \multicolumn{3}{|l|}{ Cluster } & \multirow{2}{*}{$\begin{array}{l}p \text { Value for } \\
\text { differences } \\
\text { across } \\
\text { groups }\end{array}$} \\
\hline & $\begin{array}{l}\text { "Reluctant" } \\
n=67(\%)\end{array}$ & $\begin{array}{l}\text { "Easygoing } \\
n=191(\%)\end{array}$ & $\begin{array}{l}\text { "Adamant" } \\
n=184(\%)\end{array}$ & \\
\hline \multicolumn{5}{|l|}{ Sex } \\
\hline Male $(n=225)$ & 43.7 & 57.2 & 57.8 & \multirow[t]{2}{*}{$\mathrm{p}=0.196$} \\
\hline Female $(n=207)$ & 56.4 & 42.8 & 42.2 & \\
\hline \multicolumn{5}{|l|}{ Educational attainment } \\
\hline High school $(\mathrm{n}=91)$ & 17.4 & 24.6 & 30.2 & \multirow{4}{*}{$\mathrm{p}=0.425$} \\
\hline Completed high school $(n=159)$ & 40.7 & 37.7 & 40.6 & \\
\hline College/technical school $(\mathrm{n}=87)$ & 25.3 & 18.1 & 15.3 & \\
\hline Completed university $(\mathrm{n}=89)$ & 16.6 & 19.6 & 13.9 & \\
\hline \multicolumn{5}{|l|}{ Marital status (\%) } \\
\hline Never married $(n=119)$ & 35.3 & 29.7 & 22.8 & \multirow{3}{*}{$\mathrm{p}=0.400$} \\
\hline Married $(n=224)$ & 53.0 & 57.5 & 60.8 & \\
\hline Widowed/divorced/separated $(n=87)$ & 11.7 & 12.8 & 16.4 & \\
\hline Mean age $(n=432)$ & 33.7 & 38.1 & 43.0 & $\mathrm{p}<0.001$ \\
\hline \multicolumn{5}{|l|}{ Less-than-daily smoker (\%) } \\
\hline Yes $(\mathrm{n}=78)$ & 34.1 & 19.7 & 6.7 & \multirow[t]{2}{*}{$\mathrm{p}<0.001$} \\
\hline No $(n=354)$ & 65.9 & 80.3 & 93.3 & \\
\hline \multicolumn{5}{|l|}{ Stage of change $(\%)$} \\
\hline Precontemplation $(n=196)$ & 21.0 & 40.3 & 63.5 & \multirow{3}{*}{$\mathrm{p}<0.001$} \\
\hline Contemplation $(\mathrm{n}=144)$ & 50.8 & 38.0 & 26.5 & \\
\hline Preparation $(n=74)$ & 28.3 & 21.7 & 10.0 & \\
\hline \multicolumn{5}{|l|}{ Spouse/partner smokes (\%) } \\
\hline Yes $(n=119)$ & 43.6 & 49.0 & 64.9 & \multirow{2}{*}{$\mathrm{p}=0.057$} \\
\hline No $(n=105)$ & 56.4 & 51.0 & 35.1 & \\
\hline \multicolumn{5}{|l|}{ Live with one or more smokers (\%) } \\
\hline Yes $(n=182)$ & 43.7 & 51.9 & 59.1 & \multirow[t]{2}{*}{$\mathrm{p}=0.150$} \\
\hline No $(n=243)$ & 56.4 & 48.2 & 40.9 & \\
\hline \multicolumn{5}{|l|}{ All/most friends smoke (\%) } \\
\hline Yes $(n=145)$ & 35.0 & 33.9 & 40.9 & \multirow[t]{2}{*}{$\mathrm{p}=0.503$} \\
\hline No $(n=286)$ & 65.0 & 66.1 & 59.1 & \\
\hline
\end{tabular}

stance towards smoking in their home, and their likelihood of signalling disapproval of second hand smoke. However, "laissez-faire" nonsmokers were more willing than "unempowered" non-smokers to accommodate a smoker by sitting in the smoking section of a restaurant and to accept seating in the smoking section of a restaurant if there was no room in the non-smoking section.

We compared sociodemographic and smoking related characteristics across clusters for both smokers and non-smokers. With respect to smokers (table 3), significant $(\mathrm{p}<0.001)$ differences in mean age, smoking status, and stage of change (readiness to quit) were found among the three groups. Specifically, "adamant" smokers were more likely to be older, to be daily (as opposed to less than daily) smokers, and they were more likely to be in the precontemplation stage. "Adamant" smokers also tended to have a spouse or partner who smoked $(\mathrm{p}=0.057)$. "Reluctant" smokers were more likely to be younger and to be in the contemplation phase of readiness to quit. Differences between clusters with respect to sex, educational attainment, marital status, whether they lived with one or more smokers, and whether all or most of their friends smoked were not significant at the $\mathrm{p}=0.05$ level, though they were generally in the expected direction. With respect to non-smokers (table 4), the comparison revealed significant $(\mathrm{p}<0.001)$ differences in educational attainment, mean age, former smoking status, and social situation (regarding the presence of smokers) between the three groups, and modest differences in sex distribution, but no significant differences with respect to marital status. Specifically, "adamant" non-smokers were more likely to be younger, to have higher educational attainment, and were less likely to live with a spouse who also smokes. "Laissez-faire" non-smokers were more likely to be male, have lower educational attainment, be former smokers ( $45 \%$ of this subgroup), and have smokers in their social networks.

To assess further the validity of the derived typologies, we compared responses on other survey items where distinctions would be expected. Significant differences between "reluctant", "easygoing", and "adamant" smokers were observed in the expected direction with respect to composite scores for questions on the health effects of active and passive smoking $(\mathrm{p}<0.001)$, restrictions on smoking in public places $(\mathrm{p}<0.001)$, and predicted compliance with more restrictions on smoking ( $p<0.001)$. "Adamant" smokers are less likely to acknowledge the health risks associated with active and passive smoking, are less supportive of restrictions on smoking in public places, and are more likely than either "reluctant" or "easygoing" smokers to indicate that they would not necessarily comply with more restrictions on smoking. In all but two cases, "easygoing" smokers fell between "reluctant" and "adamant" smokers in their views, as we would have predicted. These exceptions are: (a) support for restrictions on smoking in public places, which is essentially the same among "reluctant" and "easygoing" smokers; and (b) predicted likelihood of not complying with further restrictions ("ignoring the rules"), where the sample size is small ( $n=38$ comprising all three groups).

As postulated, we found significant differences among the three groups of non-smokers in the expected direction with respect to composite scores for questions on the health effects of active and passive smoking $(p<0.001)$, and support for restrictions on smoking in specific public places $(p<0.001)$. "Adamant" non-smokers are the most likely to identify the health effects associated with active and passive smoking, and to be supportive of restrictions on smoking in public places, whereas "laissez-faire" non-smokers were least likely to identify the health risks and were less supportive of restrictions. "Unempowered" non-smokers fell in between, but tended to be closer to the "adamant" than to the "laissez-faire" non-smokers.

\section{Discussion}

The ability to identify and segment smokers and non-smokers into discrete groups based on their attitudes and behaviours regarding smoking, environmental tobacco smoke, and smoking restrictions has several potentially important implications for policy makers and public health practitioners. First, it is important to know the proportions of the population that are supportive of smoking restrictions, either in their attitudes alone, or in 
Table 4 Sociodemographic and smoking related characteristics by cluster (non-smokers)

\begin{tabular}{|c|c|c|c|c|}
\hline \multirow[b]{2}{*}{ Characteristic } & \multicolumn{3}{|l|}{ Cluster } & \multirow{2}{*}{$\begin{array}{l}p \text { Value for } \\
\text { differences } \\
\text { across } \\
\text { groups }\end{array}$} \\
\hline & $\begin{array}{l}\text { "Laissez-faire } \\
n=281(\%)\end{array}$ & $\begin{array}{c}\text { "Un-empowe } \\
n=456(\%)\end{array}$ & $\begin{array}{c}\text { redAdamant" } \\
n=595(\%)\end{array}$ & \\
\hline \multicolumn{5}{|l|}{ Sex } \\
\hline Male $(n=625)$ & 52.6 & 41.4 & 47.2 & \multirow[t]{2}{*}{$\mathrm{p}=0.031$} \\
\hline Female $(\mathrm{n}=707)$ & 47.4 & 58.6 & 52.8 & \\
\hline \multicolumn{5}{|l|}{ Educational attainment } \\
\hline$<$ High school $(\mathrm{n}=193)$ & 21.6 & 18.0 & 11.3 & \multirow{4}{*}{$\mathrm{p}<0.001$} \\
\hline Completed high school $(\mathrm{n}=388)$ & 35.2 & 33.8 & 28.4 & \\
\hline College/technical school $(\mathrm{n}=313)$ & 23.0 & 22.0 & 23.7 & \\
\hline Completed university $(\mathrm{n}=428)$ & 20.3 & 26.2 & 36.6 & \\
\hline \multicolumn{5}{|l|}{ Marital status } \\
\hline Never married $(n=302)$ & 23.8 & 19.2 & 24.6 & \multirow{3}{*}{$\mathrm{p}=0.109$} \\
\hline Married $(n=796)$ & 61.3 & 68.5 & 65.8 & \\
\hline Widowed/divorced/separated $(n=220)$ & 14.8 & 12.3 & 9.6 & \\
\hline Mean age $(n=1332)$ & 46.3 & 48.4 & 41.3 & $\mathrm{p}<0.001$ \\
\hline \multicolumn{5}{|l|}{ Former smoker } \\
\hline Yes $(n=436)$ & 44.8 & 30.9 & 28.1 & \multirow[t]{2}{*}{$\mathrm{p}<0.001$} \\
\hline No $(n=896)$ & 55.2 & 69.1 & 72.0 & \\
\hline \multicolumn{5}{|l|}{ Spouse/partner smokes } \\
\hline Yes $(n=109)$ & 28.8 & 14.2 & 5.7 & \multirow[t]{2}{*}{$\mathrm{p}<0.001$} \\
\hline No $(n=687)$ & 71.2 & 85.8 & 94.3 & \\
\hline \multicolumn{5}{|l|}{ Live with one or more smokers (\%) } \\
\hline Yes $(n=174)$ & 35.0 & 16.8 & 10.6 & \multirow[t]{2}{*}{$\mathrm{p}<0.001$} \\
\hline No $(n=867)$ & 65.0 & 83.2 & 89.4 & \\
\hline \multicolumn{5}{|l|}{ All/most friends smoke } \\
\hline Yes $(n=106)$ & 15.3 & 5.5 & 7.5 & \multirow[t]{2}{*}{$\mathrm{p}<0.001$} \\
\hline No $(n=1221)$ & 84.7 & 94.6 & 92.5 & \\
\hline
\end{tabular}

both their attitudes and behaviour. Our data suggest that some segments of both the smoking and non-smoking population are potential allies in the tobacco control effort, and knowledge of their characteristics and relative proportions could be helpful in galvanising public and political support for more restrictions.

However, second, some segments of both the smoking and non-smoking population are relatively unsupportive of smoking restrictions. Non-smokers who are not committed to smoking restrictions attitudinally or behaviourally (the "laissez-faire" group) are a group that the tobacco industry might try to exploit. Although only one in five non-smokers in Ontario reports attitudes and behaviour that are relatively non-supportive of restrictions, tobacco control advocates should not overlook the potential for the industry to co-opt this segment of the population for its own purposes to create the illusion that lack of support is more widespread than it is, or to create the appearance of support for an industry position favouring "common courtesy" as an alternative to legislation. ${ }^{26-28}$ Knowing the characteristics of this group and its size, both currently and over time, may help to provide a more accurate picture of support for restrictions, as well as opportunities for social marketing.

Third, in classifying smokers and nonsmokers, themselves, into distinct groups, the emphasis shifts from aggregate support for specific control options, to the unique constellations of attitudes and behaviours of subgroups of smokers and non-smokers. Tailored strategies may be needed to influence the thinking of subcategories of smokers or non-smokers on various configurations of tobacco control measures.

Fourth, in any jurisdiction, it would be useful to know the proportions of smokers and non-smokers in each of the clusters we have identified, and whether or not these proportions vary with the specific tobacco control environment in which the population lives or with other contextual factors. Further, within specific populations, how are these proportions changing over time? In previous work, ${ }^{12} 1315$ we have shown that smokers in Ontario are much less supportive of tobacco control measures than are non-smokers. The findings of this study, however, point to the heterogeneity of both smokers and nonsmokers with regard to attitudes and behaviours regarding smoking and smoking restrictions. Further, they suggest that, in Ontario, a majority of smokers, comprised of the "reluctant" and "easygoing" groups, are potential supporters of smoking restrictions, if they are approached with sensitivity and with messages that reflect and build on their unique stance. For example, $85 \%$ of "reluctant" and "easygoing" smokers agreed that "everything possible should be done to reduce smoking", and $70 \%$ agreed that restrictions should be increased to help smokers quit. This also translates into action: one in three "reluctant" smokers, and one in five "easygoing" smokers, compared to one in 10 "adamant" smokers, claim to maintain smoke free homes.

Fifth, it is important to know how many smokers are not supportive of smoking restrictions. We were surprised at the size of the adamant group in our sample (42\%). This appears to be a group "to be reckoned with", as noted by many smokers in the qualitative research. Different approaches may be needed to address the attitudes and behaviours of this group. Yet it is noteworthy that, despite their unfavourable attitudes and behaviours, a clear majority (68\%) of "adamant" smokers predicted that they would go along with more restrictions on smoking. This finding provides little support for the tobacco industry's predictions that smokers' revolts are likely outcomes of more restrictions.

Sixth, the "unempowered" group of non-smokers may warrant particular attention from the tobacco control community. These non-smokers resemble the "adamant" nonsmokers in attitudes, but much less so in their behaviour. The challenge for tobacco control advocates is to help empower these non-smokers so that they feel more comfortable acting on their convictions. It could be that many smokers misread the behaviour of "unempowered" non-smokers as evidence that they are not concerned about second hand smoke. Because this group makes up a third of the Ontario population, their addition to the ranks of non-smokers supportive in their behaviour would contribute substantially to the public manifestation of support for restrictions on smoking in this jurisdiction, and possibly to less acceptance of exposure to environmental tobacco smoke among both non-smokers and smokers. 
Whether the failure to behave in ways consistent with their attitudes is based on a desire to accommodate smokers or a reluctance to risk confrontation is unclear, though qualitative research with a subsample of study participants conducted after the survey suggests the latter. ${ }^{20}$ This group of non-smokers does not appear to feel sufficiently empowered to make their wishes known, and interventions could focus on building skills, confidence and nonconfrontational options for being more assertive about exposure to environmental tobacco smoke. Participants in the ancillary qualitative research project indicated that the reduced social acceptability of smoking, together with wider prevalence of signage indicating restrictions on smoking in public places, was itself empowering of non-smokers. ${ }^{20} 29$

The strengths and limitations of this study must be noted. The construction of categories involves the creation of a "typical case" that is grounded in the data and that unites a group of statements or experiences, with the understanding that in reality few people may conform exactly to one category, but are nonetheless recognisable through them. These categorisations should make intuitive sense, capture the range of experience presented by respondents, and be recognisable to them. Our intention is not to suggest that these are rigid watertight categories. We do not preclude the possibility (indeed likelihood) that individuals will have feelings, express attitudes, or behave in ways resembling another category, depending on the immediate social context. Rather, the postulated categories may be thought of as indicative of the central tendencies of different groups of smokers and non-smokers.

A strength of this study was the inclusion of items encompassing both attitudes and self-reported behaviour. An exclusive focus on the former might, for example, have inflated the ranks of the "adamant" non-smoker category. Including both dimensions allowed for a more robust profile of each subgroup on the basis of a combination of attitude and self reported behaviour. Further, the ability to examine attitudes and behaviour conjointly makes it clear that these constructs cannot necessarily be assumed to be congruent. The inclusion of situational, abstract, and behavioural recall questions dealing with attitudes and behaviours, and the robustness of our findings, suggest that the proposed typologies are valid. Clearly, replication of these findings in another sample using the same or similar methods would enhance the reliability of our findings. However, it should be emphasised that the random division of our sample into "calibration" and "confirmation" halves allowed us to examine replicability.

Because the study was cross sectional, we were not able to determine if and how attitudes and behaviours change over time. We also acknowledge the potential for an unknown but likely small minority of adamant smokers who answered "yes" to the question "do you care if other people know you smoke?", because they want to make their smoking status known (that is, wear it as a badge), would have been misclassified as "reluctant" smokers in our typology. Nor can we dismiss the possibility that our results reflect what respondents are prepared to reveal in the context of a formal telephone survey interview, as opposed to what actually transpires in practice. In other words, the data cannot be entirely divorced from their methods of collection and the social context of the interaction between the interviewer and the respondent. This is perhaps why longitudinal surveys might not help as much as one would hope in revealing the variability of situated behaviour in daily lived experience. Thus, to determine adequately what people actually say and do (as opposed to what they tell us they say and do) would require participant observation in so called "natural" settings. This could be combined with multiple in-depth interviews with a small sample of smokers and non-smokers designed to explicitly explore behavioural variations and "exceptions" to the rule.

Several other avenues for further research suggest themselves. First, it would be helpful if our work was replicated in another sample, using the same (or similar) survey questions. Second, follow up qualitative research with smokers and non-smokers would be helpful. Do they intuitively recognise themselves and their friends and colleagues in these descriptions? Do they see these categories as situational or more enduring characterisations of general dispositions towards smoking and smoking restrictions? Finally, are all 10 or 11 items required for an accurate classification, or can a "short" version be developed with adequate predictive power? The latter is particularly germane for surveillance activities.

Last, but not least, given that tobacco control measures vary considerably from one jurisdiction to another, and that this has a bearing on (and is shaped by) public opinion, it is important to be mindful of the context in which these data were collected. At the time of data collection, restrictions on smoking in public places were governed by the Ontario Tobacco Control Act at the provincial level. The Act prohibits smoking in the buildings and ground of public schools and licensed day nurseries as well as in establishments where goods and services are sold, including financial institutions, video and amusement arcades, public transit shelters and stations, self serve laundries, and hairdressing establishments and barber shops. The Act also restricts smoking (without prohibiting smoking) in various locations (for example, hospitals, colleges, and shopping malls). In addition to provincial legislation, municipalities may enact bylaws to prohibit or restrict smoking in most public areas. Although $18 \%$ of Ontario municipalities had smoking bylaws by May 1996, they covered $85 \%$ of the population. However, only two municipalities were considered to have "very strong" or "complete" restrictions on smoking. ${ }^{30}$ 


\section{Conclusion}

In conclusion, our findings indicate the systematic heterogeneity of the attitudes and behaviours of smokers and non-smokers with regard to smoking restrictions. This heterogeneity has important implications for tobacco control. A better understanding of nonsmokers' attitudes and behaviour can help to mobilise public and political support for smoking restrictions measures, counter tobacco industry misrepresentations regarding the extent of opposition to such measures, and respond to industry strategies aimed at subverting effective tobacco control measures. Specifically designed approaches and strategies aimed at particular types of smokers and nonsmokers might be effective in building support for tobacco control among them. Further research is needed, not only to replicate these findings in other populations, but to refine the measurement instrument for defining typologies of smokers and non-smokers.

This study was funded by Health Canada through the National Health Research and Development Program. During the study, Dr Bull was a National Health Research Scholar. The Institute for Social Research at York University conducted the field component of the survey. The authors thank David Northrup for valuable advice on many aspects of the study's design and conduct. The project was initiated and analysed by the investigators. The helpful comments of three anonymous reviewers and the editors of Tobacco Control are also gratefully acknowledged. The ideas expressed herein remain nonetheless the final responsibility of the authors, and do not necessarily reflect those of Health Canada or Tobacco Control.

1 Fagerstrom KO, Schneider NG. Measuring nicotine dependence: a review of the Fagerstrom Tolerance Questionnaire. F Behav Med 1989;12:159-82.

2 Heatherton TF, Kozlowski LT, Frecker RC, Fagerstrom KO. The Fagerstrom test for nicotine dependence: a revision of the Fagerstrom tolerance questionnaire. $\mathrm{Br}$ Addiction 1991;86:1119-27.

3 Kozlowski LT, Porter CQ, Orleans CT, Pope MA, Heatherton TF. Predicting smoking cessation with self-reported measures of nicotine dependence: FTQ, FTND, and HSI. Drug Alcohol Depend 1994;34:211-16.

4 Pierce JP, Farkas AJ, Gilpin EA. Beyond stages of change: the quitting continuum measures progress towards suc-
cessful smoking cessation. Addiction 1998;93:277-86.

5 Prochaska JO, Velicer WF. The transtheoretical model of health behavior change. Am 7 Health Promotion, 1997; 12:38-48.

6 DiClemente CC, Prochaska JO, Fairhurst SK, Velicer WF, Velasquez MM, Rossi JS. The processes of smoking cessation: an analysis of precontemplation, contemplation and preparation stages of change. $\mathcal{F}$ Consult Clin Psychol 1991 59:295-304.

7 Husten CG, McCarty MC, Giovino GA, Chrisman JH, Zhu BP. Intermittent smokers: a descriptive analysis of person who have never smoked daily. Am $f$ Public Health 1998;88:86-9.
8 Gilpin E, Cavin SW, Pierce JP. Adult smokers who do not smoke daily. Addiction 1997;92:473-80.

9 Ashley MJ, Cohen JE, Bull SB, Ferrence R, Pederson LL, Poland BD. Less-than-daily smokers: do they differ from daily smokers in their knowledge about tobacco and their attitudes toward tobacco control? Fifth Annual Meeting of the Society for Research on Nicotine and Tobacco, 1999; San Diego, California.

10 Cohen JE, Pederson LL, Ashley MJ, Bull SB, Poland BD. Is 'stage of change' related to knowledge of health effects and support for tobacco control? Addict Behav (in press)

11 Lacchetti C, Cohen J, Ashley MJ, Ferrence R, Bull SB, deGroh M. Nicotine dependence, it's relation to smokers' behaviours, knowledge, and support for tobacco control. Report submitted to Health Canada. Toronto: Ontario Tobacco submitted to Health

12 Ashley MJ, Cohen J, Bull S, et al. Knowledge about tobacco and attitudes toward tobacco control: how different are smokers and nonsmokers? Can $\mathcal{F}$ Public Health In press.

13 Ashley MJ, Bull SB, Pederson LL, Support among smokers and nonsmokers for restrictions on smoking. Am $\mathcal{F}$ Prev Med 1995;11:283-7.

14 Martin G, Steyn K, Yach D. Beliefs about smoking and health attitudes toward tobacco control measures. South African Med F 1992;82:241-5.

15 Pederson L, Bull S, Ashley MJ, Lefcoe NM. A population survey in Ontario regarding restrictive measures on smoking: relationship of smoking status to knowledge, attitudes ing: relationship of smoking status to knowledge, attitudes

16 McAllister I. Public opinion in Australia on restricting smoking in public places. Tobacco Control 1995;4:30-5.

17 Brenner H, Born J, Novak P, Wanek V. Smoking behavior and attitudes towards smoking regulations and passive smoking in the workplace. Prev Med 1997;26:138-43.

18 Poland BD, Taylor SM, Eyles J, White NF. Qualitative evaluation of the Brantford COMMIT intervention trial: the smokers' perspective. Health and Canadian Society 1994;2:269-316.

19 Poland B. From Concept to practice in community mobilization for health: a qualitative evaluation of the Brantford COMMIT intervention for smoking cessation. Hamilton, Ontario: intervention for smoking cessation. Hamilton,

20 Poland BD, Stockton L, Ashley MJ, et al. Interactions between smokers and non-smokers in public places: between smokers and non-smokers in public places:
qualitative study. Can f Public Health 1999;90:330-3.

21 Ashley MJ, Pederson L, Poland BD, Bull S, Ferrence R, Cohen J. Smoking, smoking cessation, tobacco control and programming: a qualitative and quantitative study. Final report, NHRDP Project No. 6606-6006-801. Toronto, Ontario, 1997.

22 O'Rourke D, Blair J. Improving random respondent selection in telephone surveys. Fournal of Marketing Research 1983;20:428-32.

23 SPSS, I. SPSS Base 9.0 user's guide. 1998, Chicago, Illinois: SPSS, 1998.

24 Bailey KD. Typologies and taxonomies: an introduction to classification techniques. Thousand Oaks, California: Sage, 1994.

25 StataCorp. Stata Statistical Software: Release 6.0. College Station, Texas: Stata Corporation, 1999.

26 Cardador T, Hazan AR, Glantz SA. Tobacco industry smokers' rights publications: a content analysis. Am f Public Health 1995;85:1212-17.

27 RJ Reynolds Tobacco Company. The second-hand smokescreen (advertisement). The New York Times, 11 June 1985.

28 Anon. Tobacco and tolerance: blowing smoke. The Economist, 20 December, 1998.

29 Poland BD. The 'considerate' smoker in public space: the micro-politics and political economy of 'doing the right thing'. Health \& Place 2000;6:1-14

30 Asbridge M, O'Grady B, Abernathy T. Municipal smoking by-laws in Ontario: a review of the legislation. Working paper series No.29. Toronto, Ontario: Ontario Tobacco Research Unit, 1997 